\title{
Media social literacy in Indonesian language teaching/learning at vocational high school
}

\author{
Nurmalina
}

University Pahlawan, Pekanbaru - Indonesia, (nurmalina1812@yahoo.com)

\begin{abstract}
The disparagement of Indonesian language in academic sphere frequently occurs. The writing's culture which must be grammatically and culturally correct has begun to fade away and the emergences of a variety of social media were the causes of this disparagement. Consequently, it weakened the learners' reasoning ability and language skills. This study, therefore, aimed at identifying the causes of this disparagement where the locus of the research was at SMK Global Cendikia Kecamatan Tambang, Kampar, Riau. This study used sequential mixed methods of describing the causes. The results showed that the cognitive aspects were the focus on the Indonesian language learning; the ability of media literacy of SMK students on functional consuming literacy has been classified high, critical consuming literacy is low, functional presuming literacy was still categorized low, critical presuming literacy was low, and the low level of social media literacy ability of Indonesian learning success has not been maximally reached. It is, therefore, necessary to solve these problems by implementing learning strategies to improve the ability of good, correct and polite language and productive literary skills as well as to improve the ability of social media literacy students.
\end{abstract}

Keywords: media social literacy, indonesian language teaching/learning, vocational high school

\section{Introduction}

National Examination (NE) for Indonesian language lesson at the senior high schools' level has significantly decreased in the last 3 years. By 2015, the mean socre of SMA's NEwas at 61.29, by 2016, the mean socre of SMA's NEslumped from 6.51 points to 54.78. Again, in 2017, the mean socre of SMA's NEdrastically slumped from 4.36 points to 50.42 . The apprehensiveNE's scoreswere due to Indonesian language lessons wereunderestimated. They thought that Indonesian is often used as a means of communication. Besides, there was a negative stigma about learning Indonesian that the material taught only refers to the reading. In addition, the low ability of teachers in understanding Indonesian language itself will have a significant effect on the level of students' understanding. The disparagement of Indonesian in academic circles is now very common. The writing's culture/habit, the ability of mastering correct Indonesian grammar, the proficiencies of having oral communication and culturally have polite speech acts have begun to fade away. 
Rendrasari (2013) in her research found that the factor causing the occurrence of students' slang (prokem)language was because of being up-to-date. The use of prokem language among teenagers also spread to the virtual world such as social media. The language used among teenagers can damage the standard Indonesian language. The ethics of young people's language that can sometimes create a brash impression when written messages are stylish and slick, full of abbreviations and spellings that are very far from EYD (enhanced spellings)frequently appear in short messages or email addressed to the teachers, lecturers, and parents(Swandy, 2017).

Research results Roem et.al (2013) suggests that nearly $60 \%$ of the students accessed social media, such as facebook, during the teaching and learning process took place. This indicated that they were more often online than listening to the lessons their teachers explain. Despite of usinghigh-level technology in their daily lives, very few students used it for learning purposes.

The results of research conducted by $\mathrm{Li}$ (2016) show that social media is an ideal tool for public participation in promoting democracy. If the habits and information are not accompanied by the ability of students' literacy, it will result in the destruction of mindset and perspective, even mental teenagers Indonesia. Cayari (2011) states that the variety of social media that emerges and become the latest trend for the public requires users to have self-control in its use. Its existence also greatly affect the grammar. If used to make mistakes in the language, it can trigger a person wrong in doing reasoning. Impact, one must be difficult to reach the literacy's engineering to empower the reason with the weakness of having grammatically correct language skills so that it forms the involutive Indonesian dynamics.

Such aspects should be sought the best way-out so that the teenagers are not left-behind in the progress of existing technology. One of the way-outs is through the utilization of social media literacy in learning Indonesian. By utilizing social media as a medium of learning Indonesian is believed to be more interesting in the learning process and can motivate students. So, what is required now is reinforcement to the people who interact with the social media through an attempt to better understand the social media is social media literacy. Through social media literacy, the learning effort for the media audiences to become a life-sustaining audience in the midst of a world called the medium-saturated world(Iriantara, 2009).

Media Literacy in New Media Literacy perspective contained in the new media literacy framework created by Lin et.al. (2013) are as follows.

1. Functional Consuming. Functional Consuming is one's ability to access media content and understand its textual meaning. The indicators of Functional Consuming are firstly Consuming skills. This refers to a set of technical capabilities that individuals need when consuming media content. For example, a teenager needs to know how to operate gadgets like smartphones, laptops and more, how to use internet information technology, especially social media. Secondly, Understanding. This is the individual's ability to capture the meaning of media content appropriately at the literal level, including the ability of adolescents to capture other people's ideas published through social media in different forms such as text, images, video, etc. and capabilities to interpret the meaning of a recent short format like emoticons.

2. Critical Consuming. This is the ability to interpret the media content in a specific social, economic, political, and cultural context. The indicators of Critical Consuming consist of: a) Analysis which focuses on the individual's ability to deconstruct the messages contained in media content. Unlike the understanding described above, this indicator can be seen as a 'textual analysis' of semiotics focusing on language, genre, and code; b) Synthesis which refers to the individual's ability to remix media content by integrating their own viewpoints and for constructing media messages. For example adolescents can compare information / media content existing in social media with the same theme from different sources; c.Evaluation refers to the individual's ability to question, criticize, and doubt the credibility of a media content. Compared to the above analysis and 
synthesis, this indicator represents much higher criticism. In this evaluation requires adolescents to interpret social media content by considering issues such as identitias (author), source certainty, information updates or not. Evaluation also involves a decision-making process.

3. Functional Prosuming. It focuses on the ability to participate in creating media content. Functional Prosuming consists of three indicators, namely: a) Prosuming Skill refers to the technical skills required of individuals to produce or create media content. Such as the ability of teenagers to use the software (software) or applications available in the gadget to produce digital products (new content) such as pictures, videos, and others; b) Distribution refers to the ability of individuals to disseminate information they possess. Examples of relevance include adolescent ability to use build-in functionality on social media to share their feelings (eg likes or dislikes), to share messages or media content, and rate a product or service, and enable sharing or sharing services on facebook, line, and others; c) Production is the ability to duplicate (in part or in whole) or mix media content. Production actions include writing text in digital format, creating videos by combining images and audio, and online writings on social media such as facebook, uploading videos in youtube and other social media.

4. Critical Prosuming.Critical Prosuming is the individual contextual interpretation of media content during their participation activities, including: a) Participation, refers to the ability to participate interactively and critically in social media. Interactively emphasizes bilateral interaction between individuals. For example, teenagers are expected to actively work to build and improve the ideas of others (commented) in certain media platforms such as facebook, twitter, instagram, chat room and others.

The positive impact of social media use in learning has been expressed in the research of Castro (2012). In his research it was stated that the advantage of teaching art through social media offers an opportunity to track people's association of ideas and relationships that influence learning and artistic inquiry at various scales. Thus, it is assumed that social media literacy ability will support the implementation of Indonesian language learning.

Indonesian subject which is closely related to the readig, writin, listening, and speaking skills are highly related to the culture of literacy. In fact, the subject of Bahasa Indonesia especially in SMK Global Cendikia Kecamatan Tambang, Kampar, Riau, is not considered important by the students. According to them, Bahasa Indonesia is only a complementary subject at the school. This is supported by preliminary observations with a simple questionnaire distributed about the interest in Indonesian subject and the use of social media at SMK Global Cendikia Kecamatan Tambang, Kampar, Riau. The results of the questionnaire explained that only $30 \%$ of the students who were disseminated were interested in this subject, while $70 \%$ were less interested in Bahasa Indonesia. Related to the social media, like Facebook, $100 \%$ of students accessed social media, such as facebook.

This study aims to describe(1) the implementation of Indonesian language learning, (2) the social media literacy ability of students, (3) and the correlation of social media literacy ability of students with the success of Indonesian language learning at SMK Global Cendikia Kecamatan Tambang, Kampar, Riau. The research on social media literacy in learning Indonesian is done because the school has been running the School Literacy Movement launched by the government.

\section{Method}

This research used sequential mixed methods strategy, especially sequential exploratory strategy. The strategy of sequential mixed methods is a strategy for researcher to combine the data found from one method to another. This strategy can be done with the first interview to get qualitative data, then followed by quantitative data in this case using survey (Creswell, 2010). The setting of the research was conducted at SMK Global Cendikia school located in Kampar regency city, Riau province. The 
samples in this study were Indonesian Language Teachers and Students of Class XI SMK Global Cendikia Kabupaten Kampar, Riau Province.

\section{Results and Discussion}

The results showed that the implementation of Indonesian language learning is still on the development of cognitive aspects. The method of developing the aspects was lecture-based, especially on learning literature; the ability of the media literacy of SMK students on functional consuming literacy has been classified high, critical consuming literacy is classified low, functional prosuming literacy and critical prosuming literacy were categorised low, and the low level of social media literacy ability of Indonesian learning success has not been maximally reached. Thus, it is necessary to solve these problems by implementing learning strategies that can improve the ability of good, correct and polite language and productive literary skills in order to improve the ability of students' social media literacy.

\section{1) The Implementation of Teaching/Learning Indonesian at SMK}

Each learning process would expect to achieve every competency that has been determined and so also with learning Indonesian. For students of class XI, there were several subjects that must be mastered by learners, including text materials short stories, pantun (responsive sung poetry; quatrain) text, and explanatory text. Of the three subjects, the learners certainly expected to be able to write short stories, able to write pantun, and re-told the story. However, the learning objectives for these materials have not been fully mastered by the class XI students at SMK Global Cendikia Tambang, Kampar.

The textbook used by the teacher was CakapBerbahasa Indonesia SMK Kelas XI (Proficient in Indonesian Language SMK Class XI). Although the book is written based on the 2013 curriculum, the procedures or instructional guidelines presented do not help the teachers to achieve lesson competencies. This is due to, among others, the new 2013 curriculum applied for the academic year 2016/2017. Thus, the teacher has not fully understood the curriculum. Conventional learning model is more likely to be applied by the teachers in the learning process of Indonesian in Vocational High School, especially SMK Global Cendikia. This is evidenced by the more teachercentered learning process than the learner. In fact, the SMK learners usually prefer to be directly and actively involved than teachers in the classroom or will be better and preferred by learners if in their learning process, they become the main players or learning center of Indonesian. The results of a short interview with two Indonesian language teachers at the school concluded that they had not yet fully established a model for the Indonesian class at class XI.

The teaching materials used by teachers in the learning process of Indonesian actually have been in accordance with the curriculum and syllabus they apply. However, the content of the materials contained in the teaching materials was less interesting for the students to read. Thus, if the material itself is not read, then the expected competencies will be difficult to achieve. Under these circumstances, SMK learners ruled out the Indonesian subjects. This is evident from the results of a brief interview conducted at the school indicated that the subjects was considered important at vocational high schools were not Indonesian language.

The Indonesian language is overlooked as it is not considered important lesson, but also because the materials they need to learn are more likely to require them to be the main actors for writing and reading. These two activities are activities that are not expected by the learners. In addition, the existing reading material in the teaching materials is less interesting students to read it.

\section{2) The Ability of SMK Students' Social Media Literacy}


Based on the results of the data analysts obtained in the previous session, it can be seen that the Functional consuming literacy's mean score was 3.56 and was categorized "high". The SMK Students of Global Cendikia Tambang have been independently able to use gadgets and social media that they have without the help of others. In addition, the majority of students have also been able to capture and understand the other people's ideas conveyed in information in social media and be able to interpret the meaning or intent of emoticon used in social media.

Furthermore, the critical consumingliteracy's mean score was 2.03 and was categorized "low". The SMK students of Global Cendikia Tambang have already understood the meaning of emoticon, language, terms, and meanings contained in various forms of media content and make comprehensive observations of information content to better understand the contents of the information. In addition, the students also have been able to assess and sort out good and useful information for themselves and make comparisons with the same theme from different sources to more deeply understand the information and to find out which information better suit to their needs. However, the students' ability in evaluating an information was still quite enough. This was because some students still did not know the importance of doing an evaluation of the information they find in social media, so that when it finds information, the students tend to directly consumeit without doing evaluation first.

In Functional prosuming literacy, the obtained mean score was 2.78 and was categorized "low."The SMK students of Global Cendikia Tambang were quite capable of using some applications (software) used to create media content and distribute media / information content, where Information / media content often distributed by students relates to their personal activities, hobbies and favorite idols. However, in sharing the information/content of the media, the students rarely included links the source of information other than for credit also helps consumers to obtain more complete information. In addition, the students were still not capable enough of producing creative media content such as writing articles, videos, etc.

In Critical Prosuming Literacy, the obtained mean score was 3.17 and was certainly categorized "fairly". The majority of SMK Global Cendikia Tambang's students joined the group/fanpage in the social media. The reason the students joined the group/fanpage was because of helping them to add many friends, can exchange information with other members so that they can access more information, it fosters their interactionand critical participation indirectly such as commenting on any information provided by the members.

\section{3) The Relation of the Ability of Students' Literacy Social Media towards the Indonesian Learning's Achievement atSMK}

The importance of teaching and learning Indonesian at all levels of educations, from elementary, intermediate, to university levels, is expected to be the basis of correctly, grammatically, culturally and contextually producing Indonesian. Therefore, Indonesian should be a compulsory subject ehichmust be taken and incorporated as a requirement of passing final examination at every level of education.

The teenagers are amongst the most productive individuals in the use of social media sites because there are many opportunities for them to express themselves, socialize, engage in society, add creativity, and add new skills through social media sites (Livingstone, 2008). Learning which is appropriate to the condition of students who actively use social media will be able to increase their learning motivation. Learning using the media is one of the learning supporting should be interestingly packed for students. LearningMedia is one of the instruments for the purpose of successfully achieving learning. In Indonesian classes, media is hardly used.

Referring to its basic function, language in general is a means of communication. A child learns the language because it is urged by its need to communicate with the people around it. Therefore, 
as early as possible, the child is guided to be able to correctly communicate the Indonesian language in various situations (Ngalimun, 2014). Through the literacy's culture, the students are invited to explore to find information which have not been conveyed in learning. Media literacy moves to see the adverse effects that media messages can cause and learn to anticipate (Tamburaka, 2013). The vast amount of untrustworthy, unnecessary, manipulative, and dangerous internet content leads to a growing sense of skepticism in using the internet (Steele 2009).

A person is said to be literate if $\mathrm{s} / \mathrm{he}$ is able to understand something because of reading the right information and doing something based on his/her understanding of the content of the reading (Naibaho, 2007). During this time, the new school literacy movement is held at the stage of habituation, namely the growth of reading interest through the activities of 15 minutes to read without billing. Some schools have done second-stage literacy strategy, which provides bills after students do reading activities. However, these two things have not produced the satisfactory results because the implementation is limited to the movement. Therefore, starting in 2017, minister of education and culture has launched literacy strategy in learning Indonesian.

The main purpose of using a literacy strategy in learning Indonesian is to build students' understanding, enhance writing skills, and overall communication skills. These three things will lead to the development of character and high-level thinking skills. There has been a growing view that literacy exists only in language learning or in language classes. This opinion is certainly not incorrect because of the lush growth of literacy in the fields of mathematics, science, social sciences, engineering, art, sports, health, economics, religion, etc(cf. Robb, L in Kemdikbud, 2017).

Media literacy is an important competency which can provide awareness of the content and media impacts as well as be a control for individuals in using the media so they can choose internet content as needed. Literacy growth in schools can be done through routine and incidental activities. The activities are conducted in three stages of literacy namely the stage of habituation, development and learning (Kemdikbud, 2017).

\section{Conclusions}

The useof social media as a medium of learning Indonesian is believed to be more interesting learning process and can motivate students through literacy culture because this learning is closer to the real life of students. Implementation of social media literacy in learning Indonesian can improve students' understanding, writing skills, and communication skills thoroughly so they are able to develop high-level character and thinking skills. Implementation of Indonesian language learning at SMK Global Cendikia still on the development of cognitive aspects with lecture methods, especially on learning literature. The ability of media literacy of vocational students on functional consuming literacy is already high, critical consuming literacy is low, the functional prosuming literacy is still poor, critical prosuming literacy is low. The low level of social media literacy ability causes the success of Indonesian language learning has not been achieved maximally. Therefore, the implementation of social media literacy should be done routinely and not only limited to habituation but a measurable learning development.

\section{References}

Castro, J.C. (2012). Learning and teaching art through social media. Studies in Art Education. 52(2), 153-170.

Cayari, C. (2011). The Youtube Effect: How YouTube Has Provided New Ways to Consume. Create, and Share Music. 12/6, 1-30 . 
Creswell, J.W. (2010). Research design: pendekatankualitatif, kuantitatif, dan mixed. Yogjakarta: PT PustakaPelajar

Iriantara, Y. (2006). Media Relations Konsep, Pendekatan dan Praktik. Cetakan Pertama. Bandung: Simbiosa Rekatama Media.

Kemdikbud. (2017). Strategi Literasi dalam Pembelajaran di sekolah Menengah Pertama: Materi Penyegaran Instruktur Kurikulum 2013.

Li, Chuangying. (2016). Social Media: An Ideal Tool for Public Participation to Promote Deliberative Democracy - - The Case of Public Participation in Refugee Crisis. International Journal of Journalism and Communication. 1/2, 36-41.doi: 10.11648/j.ijjc.20160102.12

Lin, Tsin-Bin et al. (2013). Understanding New Media Literacy: An Explorative Theoritical Freamework. Educational Technology \& Society, 16 (4), 160-170 .

Livingstone, Sonia. (2008). Young People Media. London: Sage Publications [online], http://eprints.lse.ac.uk/21177/1/Young_people_new_media_(LSERO).pdf

Naibaho, Kalarensi. (2007). Menciptakan Generasi Literat Melalui Perpustakaan. Visi Pustaka, vol. 9, n. No. 3 , pp. 1-8.

Ngalimundan Noor Alfulaila.(2014). Pembelajaran Keterampilan Berbahasa Indonesia. Yogyakarta: AswajaPressindo.

Rendrasari, Retno. (2013). "Penggunaan Bahasa Alay di Facebook Siswa SMK Negeri 1 Labuan" dlm. Jurnal elektornik Program Studi Bahasa Satra Indonesia dan Daerah, Fakultas Keguruan dan Ilmu Pendidikan, Universitas Tadulako. http://jurnal.untad.ac.id.

Roem, Elva Ronaning et.al. (2013). Pengaruh Facebook bagi Pelajar Sekolah dalam Interaksionisme Simbolik di Kota Padang. Penelitian Mandiri Program Studi Ilmu Komunikasi Universitas Negeri Padang. http://repo.unand.ac.id/4003/1/BP-YD-LAP02.pdf

Steele, R. L. (2009). Traditional and New Media.Dalam W. F. Eadie (Eds),21st Century Communication A Reference Handbook (pp. 489-496). SAGE Publications, Inc.

Swandy, Eduardus. (2017). "Bahasa Gaul Remaja Dalam Media Sosial Facebook" dlm. Jurnal BASTRA Pendidikan Bahasa dan Sastra Indonesia FKIP UHO. 1:4, 1-19.

Tamburaka, Apriadi. 2013. Literasi Media. Jakarta: PT Raja GrafindoPersada. 